\title{
Rевенсн автіске: Analysis of marketing channel of tamarind in Bastar plateau of Chhattisgarh
}

\author{
Lekh Ram Verma and Kedar Nath Yadaw
}

Article Chronicle : Received : 02.11.2018;

Revised : 29.12.2018; Accepted : 05.01.2019

KEY Words : Marketing channel, Marketing surplus, Market margin, Tamarind, Bastar plateau
Author for correspondence :

\section{Lekh Ram Verma} Krishi Vigyan Kendra, Bastar (C.G.) India Email:1rextension@ gmail.com

See end of the article for authors' affiliations
SUMMARY : The present study was carried out in Bastar plateau of Chhattisgarh. Bastar plateau having total 7 districts. Out of which 2 district i.e. Bastar and Dantewada were selected purposively for this study. The study aims to assess the marketing channel of tamarind in Bastar plateau. A survey was conducted to assess the marketing channel of tamarind in selected. The survey was consisted of primary data from semi structured and pre tested interview schedule of selected respondents involved in collection and marketing of tamarind. The primary data for this study were collected from 100 respondents from the selected districts. The study findings of the study revealed that 58 per cent of the respondents preferred Channel IV (Producer $\rightarrow$ Village trader $\rightarrow$ Wholesaler $\rightarrow$ Retailer $\rightarrow$ Consumer) for the selling of their produce. A total of 620 tamarind trees owned by selected respondents and they produce total $1856.2 \mathrm{qt}$ tamarinds. From total produce, 54.80 per cent produce were sold through channel IV (Producer $\rightarrow$ Village trader $\rightarrow$ Wholesaler $\rightarrow$ Retailer $\rightarrow$ Consumer). The results of the study revealed that highest total marketing margin Rs. 3455.50/- were received from channel IV.

How to cite this article : Verma, Lekh Ram and Yadaw, Kedar Nath (2019). Analysis of marketing channel of tamarind in Bastar plateau of Chhattisgarh. Agric. Update, 14(1): 22-27; DOI : 10.15740/HAS/AU/14.1/22-27. Copyright@ 2019: Hind Agri-Horticultural Society. 